Canadian Journal of Fisheries and Aquatic Sciences Journal canadien des sciences halieutiques et aquatiques

Decay processes in woody debris influence the taxonomic and functional composition of littoral macroinvertebrates

\begin{tabular}{|r|l|}
\hline Journal: & Canadian Journal of Fisheries and Aquatic Sciences \\
\hline Manuscript ID & cjfas-2017-0364.R1 \\
\hline Manuscript Type: & Article \\
\hline Date Submitted by the Author: & $18-$ Nov-2017 \\
\hline $\begin{array}{r}\text { Complete List of Authors: } \\
\text { Is the invited manuscript for } \\
\text { consideration in a Special } \\
\text { Issue? : }\end{array}$ & $\begin{array}{l}\text { Magdalena, Czarnecka; University of Nicholas Copernicus, Department of } \\
\text { Niler, Oliver; Leibniz-Institute of Freshwater Ecology and Inland Fisheries }\end{array}$ \\
\hline Keyword: & lakes; habitat complexity; diversity; functional dispersion; \\
\hline
\end{tabular}


1 2

3

4 5

6

7

8

\section{Decay processes in woody debris influence the taxonomic and functional composition of littoral} macroinvertebrates

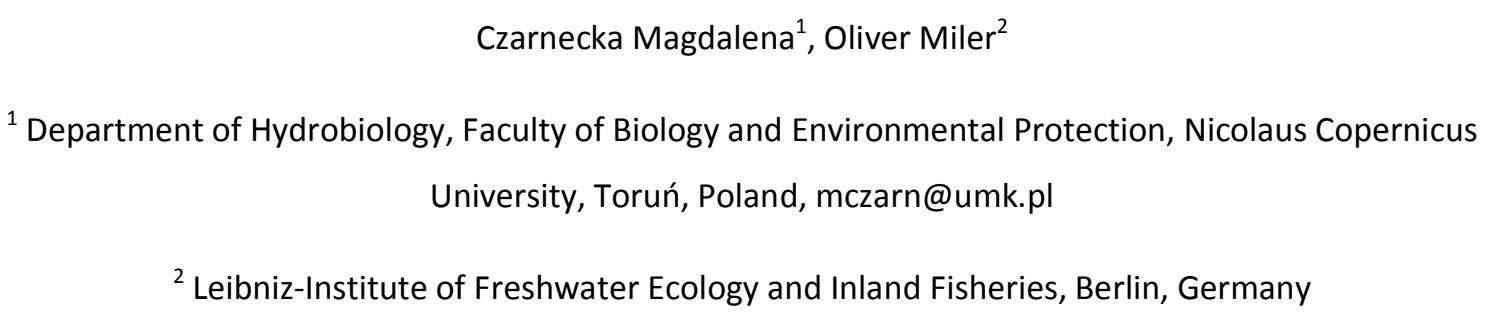

\section{Abstract}

We examined the effects of woody debris decay state of on the densities, taxonomic and functional composition, and diversity of macroinvertebrates in littoral zones of undeveloped lakes.

Our study revealed that the interacting effects of increasing roughness and softness of the wood, as well as changes in the quality of food resources with progressing decomposition of woody debris exerted the strongest impacts on macroinvertebrate communities. Structurally complex, decomposed wood supported higher densities and species richness of macroinvertebrates than undecayed wood. We also found several taxa which were typical for decayed wood, including macroinvertebrates considered as xylophages. Decaying wood underpinned greater functional richness than undecayed wood, with high densities of collector-gatherers and shredders which could benefit from organic matter originating from decomposing wooden tissue, as well as predators attracted by numerous potential prey inhabiting this complex habitat. As decaying wood enhanced abundant and diverse macroinvertebrate communities, which in turn could subsidize upper trophic levels, it provides a valuable habitat in littoral zones, particularly in lakes with already sparse macrophyte cover.

\section{Introduction}

Woody debris originating from riparian trees constitutes a common habitat in lakes in forested areas, linking terrestrial and aquatic food webs (Schindler and Scheuerell 2002; Francis and Schindler 2009). Submersed logs and branches in littoral zones provide a surface for diverse 
invertebrates utilizing wood for oviposition, pupation and emergence (Anderson et al. 1984), as a refuge (Everett and Ruiz 1993; Czarnecka et al. 2014) and source of food such as epixylic biofilm or fine particulate organic matter (FPOM) retained by woody structures (Eggert and Wallace 2007; Francis et al. 2007). On the other hand, macroinvertebrates colonizing wood subsidize many fish species which search food and shelters among logs (Lewin et al. 2004; Sass et al. 2006, 2012). Thus, woody debris supports the productivity of littoral zones and contributes to greater abundance and diversity of littoral communities, particularly at sites with a high density of wood (Schindler et al. 2000; Schneider and Winemiller 2008).

Woody debris in aquatic ecosystems is subjected to long-lasting degradation which is triggered by microbes and invertebrates, namely burrowers and scrapers damaging the wood surface (Dudley and Anderson 1982; Harmon et al. 1986; Guyette et al. 2002). Hence, in littoral zones, freshly introduced undecayed wood occurs together with wood in various stages of decomposition (Smokorowski et al. 2006). Decay processes soften the wood and result in the appearance of numerous grooves and pits on its surface (Pereira et al. 1982; Harmon et al. 1986). Greater roughness of the wood can have positive effects on the abundance and biomass of macroinvertebrates, as it offers numerous shelters protecting against predators (Czarnecka et al. 2014) and increases the retention of FPOM on the rugged surface (O'Connor 1991). As has been shown in streams, the progressive decay of the wood may also alter trophic conditions and thus influence the taxonomic and functional composition of macroinvertebrates (Golladay and Webster 1998; Collier and Halliday 2000), supporting communities which could benefit from diverse food resources such as epixylic microbes (fungi, bacteria), wooden tissue and FPOM (Dudley and Anderson 1982; Eggert and Wallace 2007). Consequently, not merely high densities of woody debris, but also the presence of greater proportion of complex decayed wood in littoral zones could increase the abundance and diversity of macroinvertebrates as well as the complexity of food webs. However, to our knowledge, detailed studies on the impact of the decay state of littoral wood on the structure of 
macroinvertebrate communities in lakes are scarce so far and accounted only for a taxonomic composition with invertebrates identified until order or family level (Smokorowski et al. 2006).

The aim of this study was to explore how the decomposition of woody debris influences the density, taxonomic composition and diversity of macroinvertebrates in littoral zones. To gain deeper insight into the effects of wood decay on macroinvertebrate communities we also examined their functional composition and functional diversity which represents the variability of species traits or niches (Tilman et al. 1997; Cadotte et al. 2011). Functional diversity describes how an ecosystem functions and hence it provides more information than traditional diversity measures such as species richness that indicates only the presence and abundance of species (Cadotte et al. 2011; Lyashevska and Farnsworth 2011). We conducted our study in undeveloped, riverine lakes, where submerged wood is not subjected to human impact. We focused on fine woody debris (FWD) with a diameter smaller than $5 \mathrm{~cm}$ and length below $1 \mathrm{~m}$, which is usually most abundant in nearshore areas. We hypothesized that more decayed wood will support abundant and highly diverse macroinvertebrate communities due to combined effects of greater surface complexity of the wood and an increased availability of food resources such as wood tissue and FPOM. Alterations in food conditions due to progressing wood decay will be reflected in the taxonomic and functional composition of macroinvertebrates. We also expected that highly decayed wood will harbour specific woodassociated communities dominated by xylophagous species.

\section{Materials and methods}

Site description

The study was conducted in three fluvial lakes in the Drawieński National Park (NorthWestern Poland) in the course of the river Płociczna (Table 1). All lakes are located in an area with minimal impact from human disturbances; their basins are predominantly covered by forest and the riparian vegetation is dominated by deciduous trees, namely alder (Alnus spp.) and birch (Betula spp.), but also pine (Pinus sylvestris L.). Sitno and Płociczno are shallow eutrophic lakes. Ostrowiec is 
a mesotrophic lake, however, as it consists of four discrete basins, we confined our study to its northern riverine part which is clearly eutrophic (http://dpn.pl/ostrowiec-and-gluche-lake). Since all three studied lakes are characterized by low water transparency, aquatic vegetation mainly consists of floating leaved and emerged macrophytes, with only sparse occurrence of submerged vegetation. We randomly selected five sites at Sitno and Ostrowiec and three sites at Płociczno for macroinvertebrate and woody debris sampling. The sampling sites were overshadowed by trees, and were hence almost devoid of macrophytes. The bottom substrates were mainly represented by sand, except Płociczno, where soft sediment (a mixture of sand and silt) dominated. At each site we established a $10 \mathrm{~m}$ long transect, perpendicular to the shoreline, including the littoral zone at a distance of $2 \mathrm{~m}$ from the shore (up to a depth of $0.5 \mathrm{~m}$ ). This transect size was selected since approximately $80 \%$ of woody debris originates from the first $10 \mathrm{~m}$ of riparian forest landwards from the shore (Murphy and Koski 1989) and we also observed that most of FWD was confined to the upper part of the littoral zone within the reach of overhanging trees branches. To estimate the total area of woody debris available at the studied sites we counted all submerged wood pieces greater than $1 \mathrm{~cm}$ in diameter within the transect and determined their length and diameter as the average of two values measured at distal points. Subsequently, we determined the area of woody debris as the sum of all individual wood pieces per $\mathrm{m}^{2}$ of lake bottom. The collected wood was also assigned to three decay classes (Table 2). The characteristics of littoral woody debris are summarized in Table 1. The highest wood surface per $\mathrm{m}^{2}$ of lake bottom was recorded in Ostrowiec, whereas in Płociczno littoral wood was least abundant. In nearshore areas, the contribution of decayed wood (class 2 and 3) was relatively high and constituted over $50 \%$ of the whole woody debris surface area. Highly decayed wood (class 3) particularly dominated in Sitno (63\% of the total wood surface area), whereas its lowest proportion was recorded in Ostrowiec (51\% of the total wood surface area). 
In May 2014, we collected at each site pieces of FWD with diameters ranging from 1 to $5 \mathrm{~cm}$

102

103

104 and lengths up to $1 \mathrm{~m}$ and a mean surface area of $0.39 \pm 0.76 \mathrm{~m}^{2}$ SD. FWD was carefully lifted up from the bottom of the littoral zone using a dip net (500 $\mu \mathrm{m}$ mesh size). Macroinvertebrates were rinsed off with water and removed from the wood by brushing and using a forceps. The samples were stored in $96 \%$ technical Ethanol in separate bottles. All wood pieces were measured to estimate macroinvertebrate densities in individuals per $\mathrm{m}^{2}$. In the laboratory, macroinvertebrates were sorted under a stereomicroscope, counted and identified to species level, whenever possible, except Oligochaeta.

To characterize macroinvertebrate functional diversity, we assigned taxa to a set of traits based on their feeding type, food preferences, locomotion mode and maximal potential size. These traits can be influenced by the wood decay state, as progressing decomposition of the wood changes its structural complexity and quality of food resources (Golladay and Webster 1998; Collier and Halliday 2000). Moreover, more complex, decayed wood harbours greater numbers of large bodied invertebrates than undecayed wood (Czarnecka et al. 2014). Traits were scored based on information from the freshwaterecology.info data base (Schmidt-Kloiber and Hering 2011; see full reference list in Appendix A). To determine taxa specifically associated with wood, based on the existing literature, we distinguished obligate xylophagous species feeding mostly on wood: Lype phaeopa Stephens $<$ Trichoptera> (Waringer and Graf 2011), Glyptotendipes spp., Stenochironomus sp. <Chironomidae> (Dudley and Anderson 1982; Pereira et al. 1982) and facultative xylophagous species feeding on wood during certain periods in their life cycle: Acroloxus lacustris L. <Gastropoda> (Cherugi and Pattee 1991), Anabolia furcata Brauer, Halesus radiatus Curtis, Limnephilus rhombicus L. <Trichoptera> (Cherugi and Pattee 1991; Hoffmann and Hering 2000), Asellus aquaticus L. $<$ Crustacea $>$ (Schmedtje and Colling 1996), Polypedilum sordens Wulp and Phaenospectra flavipes Meigen <Chironomidae> (Dudley and Anderson 1982).

Statistical analyses 
Total densities, density of xylophagous species, taxonomic richness and taxonomic diversity

127 (Shannon's diversity index, evenness) were calculated to test the effects of FWD decay states on

macroinvertebrate communities by means of analysis of variance (ANOVA). Prior to analyses, macroinvertebrate data were log $(x+1)$ transformed to meet assumptions of normality and heteroscedasticity. Richness was rarefied for 10 individuals to assess whether any effects on taxonomic richness were simply artefacts of greater densities (Hurlbert 1971). We also examined the relationship between taxonomic richness and evenness using Pearson`s correlation. Differences in the community composition among different decay states of FWD were further explored using nonmetric multidimensional scaling (nMDS) ordination and analysis of similarities (ANOSIM), based on Bray-Curtis measures of similarity (Clarke 1993). Indicator species analysis (IndVal, Dufrêne and Legendre 1997) was used to identify macroinvertebrate species characteristic for various wood decay states. Indicator species are determined by analysing the relationship between the species occurrence or density values from a set of surveyed sites and the classification of these sites into groups (Dufrêne and Legendre 1997; De Cáceres and Legendre 2009). The classification of sites into groups can be derived from the similarities in environmental conditions among sites (e.g. habitat types), or in species composition (e.g. community) (De Cáceres et al. 2012).

As a measurement of species functional diversity, we calculated three multidimensional indices: functional richness (FRic), functional evenness (FEve) and functional dispersion (FDis), using the R package FD (Laliberté et al. 2015). Functional richness represents the amount of functional space filled by the community and it can be estimated using the minimum convex hull of trait space that includes all taxa (Villéger et al. 2008). Functional evenness describes the evenness of density distribution in a functional trait space (Mason et al. 2005), whereas functional dispersion is the mean distance of individual species to the centroid of all species in the community and simultaneously quantifies functional trait dissimilarity and evenness within communities. It also integrates information on relative densities (Laliberté and Legendre 2010). Differences in functional indices between studied types of wood were tested using ANOVA, after log $(x+1)$ transformation. 
152

153

154

155

156

157

158

159

160

161

162

163

164

165

166

167

168

169

170

171

172

173

174

175

176

\section{Results}

\section{Macroinvertebrate community on different types of wood}

Density, number of taxa and taxonomic diversity

The wood decay state significantly influenced macroinvertebrate densities $\left(F_{2,30}=10.13, p<\right.$ 0.001) (Fig. 1A). Highest mean densities of macroinvertebrates were recorded on wood with loose bark (class 2, $5715 \pm 914$ SD ind. $\mathrm{m}^{-2}$ ), while the lowest densities were recorded on undecayed wood (class $1,2140 \pm 427 \mathrm{SD}$ ind. $\mathrm{m}^{-2}$ ). There were no significant differences between mean macroinvertebrate densities on wood with loose bark and highly decayed wood (class 3, $5104 \pm 933$ SD ind. $\mathrm{m}^{-2}$ ). The contribution of xylophages to the overall density of the epixylic community was high. They particularly dominated on wood with loose bark (59\%), whereas on highly decayed and undecayed wood xylophages occurred in lower proportions ( $52 \%$ and $48 \%$, respectively). The numbers of obligate xylophagous species $\left(F_{2,30}=2.30, p=0.001\right)$ and facultative xylophages $\left(F_{2,30}=\right.$ $13.48, p<0.0001$ ) were significantly higher on more decayed wood (class 2 and 3 ) than on wood with intact bark (class 1) (Fig. 1B). Glyptotendipes pallens (Meigen) $\left(F_{2,30}=8.12, p=0.01\right), P$. sordens $\left(F_{2,30}=\right.$ 7.74, $\mathrm{p}=0.002)$, and $A$. aquaticus $\left(\mathrm{F}_{2,30}=18.54, \mathrm{p}<0.0001\right)$ were most abundant on wood with loose bark (class 2), while the highest densities of $H$. radiatus occurred on highly decayed wood (class 3 ) $\left(F_{2,30}=4.37, p=0.02\right)$. Densities of $L$. phaeopa $\left(F_{2,30}=0.30, p=0.75\right)$, Stenochironomus sp. $\left(F_{2,30}=2.41\right.$, $\mathrm{p}=0.11)$, A. lacustris $\left(\mathrm{F}_{2,30}=2.89, \mathrm{p}=0.07\right)$, A. furcata $\left(\mathrm{F}_{2,30}=0.27, \mathrm{p}=0.77\right)$, L. rhombicus $\left(\mathrm{F}_{2,30}=0.68\right.$, $\mathrm{p}=0.51)$, and $P$. flavipes $\left(F_{2,30}=2.55, p=0.09\right)$ were not related to the decay state of the wood.

The wood decay state also influenced the number of macroinvertebrate taxa and diversity indices (Fig. 2). Richness differed significantly between undecayed (class 1 ) and more decayed wood (class 2 and 3$)\left(F_{2,30}=5.80, p=0.007\right)$. The highest number of taxa was recorded on wood with loose

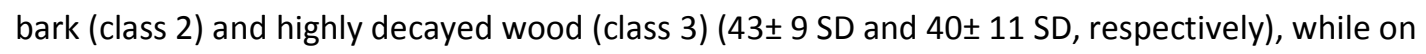
wood with intact bark (class 1$) 31$ taxa ( $\pm 8 \mathrm{SD}$ ) were found. When the numbers of macroinvertebrates on different wood classes were equalized using rarefaction, wood with loose 
177

178

179

bark and highly decayed wood were still associated with higher numbers of taxa than wood with intact bark (Fig. 3). Although there were no significant effects of the wood decay state on the Shannon-Wiener index $\left(F_{2,30}=0.26, p=0.77\right)$, evenness values differed significantly $\left(F_{2,30}=6.19, p=\right.$ 0.006) and were highest on the wood with intact bark $\left(J^{\prime}=0.33\right)$, whereas on wood with loose bark and highly decayed wood evenness values were considerably lower $\left(J^{`}=0.23\right.$ and 0.24 , respectively). We also found that taxa richness and evenness were negatively correlated $(r=-0.473 ; p=0.002)$.

\section{Taxonomic composition of the macroinvertebrate community}

The ANOSIM analysis revealed slight, but still significant differences in macroinvertebrate community composition between different wood decay states (ANOSIM, R $=0.30 ; p=0.001$ ). Similarly, a nMDS analysis showed only a small separation between macroinvertebrate assemblages

(Fig. 4). Generally, communities colonizing wood with intact bark (class 1 ) were distinctly different from those found on more decayed wood (class 2 and 3 ).

Regardless of the wood decay state, macroinvertebrate communities were dominated by $G$. pallens and P. sordens (Chironomidae). The contribution of G. pallens to total macroinvertebrate densities ranged from $33 \%$ on wood with intact bark to $42 \%$ on wood with loose bark, whereas the contribution of $P$. sordens ranged from $10 \%$ on highly decayed wood to $13 \%$ on wood with loose bark. Dicrotendipes nervosus (Chironomidae) occurred in equal proportion (6\%) on all types of wood. Nevertheless, we observed pronounced differences in the taxonomic composition of macroinvertebrates inhabiting different types of wood. On wood with intact bark we recorded high contributions of Cricotopus intersectus (Staeger) (10\%) and Cricotopus sylvestris (Fabricius) (8\%). On wood with loose bark, C. intersectus and C. sylvestris constituted $3 \%$ and $2 \%$ of macroinvertebrate densities, respectively, while on highly decayed wood their contribution was $5 \%$. With advancing decay of the wood, the contribution of Dreissena polymorpha (Pallas) strongly increased from $2 \%$ on wood with intact bark to $8 \%$ on highly decayed wood. 
IndVal analysis showed several characteristic taxa associated with loose bark and highly

decayed wood (Table 3). G. pallens, A. aquaticus, Glossiphonia paludosa (Carena 1824), Erpobdella

octoculata (L.), Helobdella stagnalis (L.) (Hirudinea), Ceratopogoninae (Diptera), Gyraulus albus

(Müller) (Gastropoda) were typical taxa for wood with loose bark while Platycnemis pennipes (Pallas)

(Odonata) and Pisidium sp. (Mollusca) were typical taxa for highly decayed wood. The two latter taxa were completely absent on wood with intact bark and their numbers systematically increased with advancing decay of the wood.

Functional composition and diversity of macroinvertebrates gatherers (CG_Bur), sprawling/walking collector-gatherers (CG_Spr), and sprawling/walking scrapers influenced the densities of several functional groups (Table 4, Fig. 5). Mean densities of burrowing active filter-feeders (AF_Bur) progressively increased with advancing decay of the wood. Mean densities of burrowing, sprawling/walking and swimming collector-gatherers (CG_Bur, CG_Spr and sprawling/walking and swimming shredders (Sh_Spr and Sh_Swm) were significantly higher on more decayed wood (class 2 and 3) than on wood with intact bark (class 1). Moreover, some functional feeding groups were absent on undecayed wood (class 1), such as burrowing and swimming predators (P_Bur and P_Swm), and sessile scrapers (Sc_Ses). Functional richness was significantly lower on the wood with intact bark than on other types of wood $\left(F_{2,36}=6.81, p=0.003\right)$. However, there were no differences in functional dispersion between wood decay states $\left(F_{2,36}=0.13, p=0.99\right)$, even though its value progressively increased with wood decomposition. Higher values of functional evenness on undecayed wood (class 1 ) indicated that functional groups were more evenly distributed

224 in comparison to more decayed wood (class 2 and 3$)\left(F_{2,36}=3.17, p=0.048\right)$.

\section{Discussion}


Our study revealed that the decay state of the wood significantly influenced the density,

227

228

number of species and evenness of macroinvertebrate communities, and to lesser extent, their taxonomic and functional composition. Decayed wood (class 2 and 3) constituted particularly valuable habitat, as it supported more abundant and taxa rich communities than undecayed wood (class 1). However, differences between wood with loose bark (class 2) and highly decayed wood (class 3) were only visible to a small extent.

The abundances of macroinvertebrates were over twofold greater on more decomposed wood (class 2 and 3 ) than on undecayed wood (class 1 ) and these results concur with findings obtained from experimental studies (Mathooko and Otieno 2002; Czarnecka et al. 2014). Decayed wood with numerous cracks, grooves and holes on the surface is characterized by a higher structural complexity which could affect the macroinvertebrate community. Many studies have reported increased macroinvertebrate densities in more complex habitats and explained this phenomenon by a greater number of niches and resources due to higher microhabitat availability allowing more species coexist (Kovalenko et al. 2012; St. Pierre and Kovalenko 2014). Moreover, this effect was independent of the habitat surface area (O`Connor 1991; Kovalenko et al. 2012). Complex woody structures which offer many attachment possibilities may also contribute to greater densities of epixylic taxa by reducing shear stress. Such an influence of wood has been shown in experimental studies for both macroinvertebrates and algae constituting a potential food source for invertebrates (Sabater et al. 1998; Gabel et al. 2008). The complex microstructure of decayed wood can also support high densities of macroinvertebrates by a provision of diverse shelters and decrease in predation events (Czarnecka et al. 2014; Czarnecka 2016). Such an effect was recorded with respect to macroinvertebrate predators and their prey (Czarnecka et al. 2014), although the interactions among macroinvertebrates and predatory fish were more intricate and represented a trade-off between different prey density, varied availability of refuge on undecayed and decayed wood, as well as species-specific abilities of invertebrates to find shelters in woody structures (Czarnecka et al. 2014; Czarnecka 2016). In our study, we observed that more decomposed wood (class 2 and 3) 
252 provided significantly greater numbers of shelters than undecayed wood (class 1), and the wood

253 assigned to class 2 and 3 both provided a similar degree of protection, as macroinvertebrates

254 efficiently exploited spaces under loose bark, as well as pits and grooves in highly decayed wood. This

255 could explain minor differences between the densities of macroinvertebrate communities inhabiting

256 both types of decayed wood.

An additional level of complexity could be also gained by accumulations of sediment directly

258

259

260

261

262

263

264

265

266

267

268

269

270

271

272

273

274

275

276 on the wood surface, as well as around wood pieces, thus contributing to greater densities of macroinvertebrates (O`Connor 1991; Francis et al. 2007). The complexity of hard surfaces may also change over time due to the development of a biotic structure from the recruitment of species (Smith et al. 2014). For instance, the appearance of aggregations of sessile molluscs provides additional sites for the attachment of invertebrates on the top of their shells, as well as in interstices between individuals, and significantly increases densities of associated macroinvertebrates (Burlakova et al. 2012). This could be also true for our study, since we recorded a systematic increase of $D$. polymorpha densities with progressive decay of FWD.

The complexity provided by the increased wood roughness can also contribute to greater taxonomic richness of macroinvertebrate communities (O`Connor 1991; Smokorowski et al. 2006). This could be explained by a high space-size heterogeneity of decayed wood providing a living place for invertebrates varying in body size (Czarnecka et al. 2014). Similar patterns can be observed in macrophytes (St. Pierre and Kovalenko 2014). We found a significantly higher species richness on more decayed wood (class 2 and 3), although we did not find differences in diversity between various classes of the wood, estimated by the Shannon-Wiener index, which combines two measures: richness and evenness. High species richness in decayed wood could have been offset by a lower evenness of the community, with less numerous macroinvertebrate species on undecayed wood being more evenly distributed. Contrary to our results, other authors have indicated a positive relationship between richness and evenness in invertebrate communities, also in complex habitats 
(Loya 1972; O`Connor 1991; Stirling and Wisley 2001). It has been argued that the taxonomic diversity of a community is governed by migration and an increase in the number of invertebrate species with time (Loya 1972; Stirling and Wisley 2001). However, based on results derived from plant communities, it has been also suggested that key ecological processes such as competition, predation and succession can alter diversity through changes in evenness without any change in species richness and such an effect can be particularly strong at small spatial scales (Stirling and Wisley 2001; Zhang et al. 2012). Considering that decayed wood in our study was subjected to longlasting succession processes, lower evenness besides high species richness could be a result of biotic interactions such as selective predation (Czarnecka et al. 2014) and/or increased recruitment of sessile molluscs (Burlakova et al. 2012), which could affect macroinvertebrate abundances, and consequently, the diversity of the community.

The taxonomic and functional composition of macroinvertebrates also revealed differences between undecayed and more decayed wood. Our results indicate that the interacting effects of increasing habitat complexity and wood softness, time of the wood exposition in water, as well as changes in the quality of food resources with progressing decomposition of FWD exerted the strongest impact on macroinvertebrates. We also found in the studied community a high contribution of macroinvertebrates closely associated with wood (obligate and facultative xylophages) which ranged from $48 \%$ on undecayed wood (class 1 ) to $59 \%$ of total invertebrate numbers on wood with loose bark (class 2).

Previous studies conducted in streams have shown that invertebrates exhibit various preferences to different decay states and softness of the wood (Anderson et al. 1984; Magoulick 1998; Collier and Halliday 2000). Undecayed wood is usually occupied by facultative colonizers, but as decomposition progresses, more specialised xylophagous species such as gougers and miners occur (Anderson et al. 1984; Magoulick 1998; Collier and Halliday 2000). They are mainly represented by chironomids constructing tunnels or galleries just under the wood surface, but also the 
302

limnephilid, lepidostomatid and psychomyiid caddisflies (e.g. Lype sp.), as well as coleopterans (e.g. Elmidae) are reported (Dudley and Anderson 1982; Anderson et al. 1984). Xylophages highly rely on nutrients derived directly from the soft wooden tissue, but also feed on wood-associated microorganisms (fungi, bacteria) (Dudley and Anderson 1982; Pereira et al. 1982; Eggert and Wallace 2007). Therefore, their densities progressively increase, as highly decayed wood provides a suitable food sources (Anderson et al. 1984; Collier and Halliday 2002). In our study, chironomids dominated in the community and they were mainly represented by mining $G$. pallens. Although this species commonly occurs in different littoral habitats such as macrophytes (Wolfram et al. 2002) or stones (Harrison and Hildrew 2001), it is also found in woody debris and can be considered as an obligate xylophage, since wooden tissue is often recorded in its guts (Dudley and Anderson 1982; Moog 1995). Densities of G. pallens were clearly related to the decay state of the wood and the IndVal analysis showed that it was particularly characteristic for wood with loose bark (class 2). According to our observations, the preference of $G$. pallens to this type of the wood was related to the possibility of mining inside the soft loose bark. We also found that three other species classified as facultative xylophages were associated with more decayed wood (class 2 and 3 ). The chironomid species $P$. sordens and the isopod A. aquaticus were most abundant on the wood with loose bark (class 2) (the latter was also an indicator species for this class of the wood), whereas the Trichoptera species $H$. radiatus was particularly numerous on highly decayed wood (class 3). Several authors recorded in guts of all these taxa wooden fragments and suggested that at certain periods of life their growth could be supported by nutrients derived from wood (Dudley and Anderson 1982; Moog 1995; Schmedtje and Colling 1996; Hoffmann and Hering 2000).

Changes in the availability of other food sources with progressing decay also exerted a strong impact on the community and this was reflected by the varying functional composition of macroinvertebrates. We found an increase in abundances of burrowing, sprawling/walking and swimming collector-gatherers and burrowing active filter-feeders on more decayed wood (class 2 and 3) which could be an effect of consistent accumulations of FPOM following decomposition (Ward 
and Aumen 1986; Collier and Halliday 2000) and/or greater sediment deposition on complex rough surfaces (O`Connor 1991). O’Connor (1991) has reported that several deposit-feeders (Chironomidae, Oligochaeta and Nematoda) particularly preferred spots with thick sediment layer on grooved snags. In our study, the burrowing filter-feeder Pisidium sp., which was a typical taxon for highly decayed wood (class 3), could be a clear example of such a preference, as it usually occupies muddy habitats with high accumulations of fine particles (Von Bertrab et al. 2013). The absence of Pisidium sp. on undecayed wood suggested that suitable conditions for its colonization were created after a long deposition of FPOM with progressing wood decomposition. Similarly, we recorded greater densities of sprawling/walking and swimming shredders on more decayed wood (class 2 and 3) which could reflect a higher availability of coarse organic matter in this habitat (Heino 2008). The abundance of shredders was particularly high on the wood assigned to class 2 and this suggests that disintegrating bark could be a valuable food source for these invertebrates. We also noticed significantly greater densities of sprawling/walking and sessile predators on more decayed wood (class 2 and 3). This complex habitat was associated with increased numbers of potential prey, but also provided better protection against other predators (e.g. fish) than structurally simpler undecayed wood. Such conditions usually attract a large number of invertebrate predators, as has been observed in macrophytes, which increased the heterogeneity of nearshore zones (Warfe and Barmuta 2006; Heino 2008). However, in our study various predatory species exploited the decayed wood in different ways. For instance, leeches that were characteristic for the wood with loose bark, attached to the smooth surface of the wood under bark cover which simultaneously could protect them against other predators. On the other hand, highly decayed wood (class 3 ) attracted numerous dragonfly larvae $P$. pennipes. Their presence can be explained by the fact that ambush predators using a sit-and-wait foraging strategy particularly benefit from high accumulations of potential prey in complex habitats, because they are able to hunt there very effectively (James and Heck 1994; Horinouchi et al. 2009). Less clear was the response of scraper species to the varying decomposition of the wood. Although we did not find a significant relationship between decay state of the wood 
and densities of burrowing, sessile and sprawling/walking scrapers, several taxa exhibited some preferences for specific types of the wood. The chironomid species $C$. intersectus and $C$. sylvestris were particularly numerous on undecayed wood, whereas the gastropod G. albus was a typical species for the wood with loose bark. Previous studies have demonstrated that scrapers grazing on epixylic biofilm constituted an important component of wood-associated communities and occurred in rather large numbers during the initial stages of wood decay due to high abundances of algae (Golladay and Webster 1988; Collier and Halliday 2000). Algae colonizing undecayed wood probably benefit from better light conditions that on decayed wood which retains high amounts of sediment. This can be confirmed by other observations showing that densities and richness of scrapers were usually negatively correlated with significant detritus depositions (Dudley and Anderson 1982; Heino 2008). Thus, these findings could explain high contribution of $C$. intersectus and $C$. sylvestris on undecayed wood in our study. However, it should be emphasized that other authors found greater chlorophyll $a$ concentrations on highly decayed wood than undecayed wood (Smokorowski et al. 2006). It has been suggested that the increased roughness of the wood could promote the development of abundant algal communities, as it offered a variety of attachment sites and protection against shear stress (Sabater et al. 1998; Schneck and Melo 2013). Less clear is the relationship of G. albus with the wood with loose bark (class 2) in our study. However, research conducted in streams has suggested that greater numbers of this species on decayed wood can be explained by the fact that its growth could be additionally supported by fungi derived from disintegrating tissue which is often scraped off the wood surface together with algae (Hoffmann and Hering 2000). In summary, more decayed wood (class 2 and 3) supported significantly greater functional richness than undecayed wood (class 1). This could be an effect of higher species richness, as well as

377 increased heterogeneity of the habitat which enhances the diversity of functional traits (Petchey and 378 Gaston 2002; Heino 2008) and, as a consequence, increases resource use efficiency (Díaz and Cabido 2001). Therefore, the presence of high proportions of decayed wood in littoral zones could enhance 
the food web complexity, as well as ecosystem functions. Nevertheless, we noted the lack of significant differences in functional dispersion (FDis) between studied types of wood, even though its values slightly increased with advancing decay. This could be an effect of lower functional evenness recorded on more decayed wood (class 2 and 3). Usually, the most functionally dispersed communities consist of evenly distributed, dissimilar traits which contribute to the maintenance of high process rates related to organic matter transformation (Frainer et al. 2014). However, decreasing trait evenness may be also linked to enhanced organic matter decomposition if the dominant trait (or group of traits) is the most productive (McKie et al. 2008; Frainer et al. 2014). In case of our study, burrowing and sprawling collector-gatherers significantly dominated on decayed wood. They are usually associated with high concentrations of nutrients in fine sediments (Heino 2008) and primarily involved in the transformation of organic matter produced in decomposition processes and retained in the littoral zone by structurally complex woody debris (Ward and Aumen 1986; Francis et al. 2007).

The results of our study suggest that decayed wood is valuable habitat contributing to greater densities and diversity of macroinvertebrates in the littoral zone. Hence, decomposed wood can provide a diversified food source supporting fish that rely on benthic resources (Schindler and Scheuerell 2002; Francis and Schindler 2009). High densities of xylophages, collector-gatherers, shredders and predators on decaying wood indicate that this is also a site of intensive metabolic activity of macroinvertebrates. Particularly xylophages and burrowing/mining species can perform important roles in nutrient cycling, since they trigger the fragmentation of wood due to damaging its surface, which exposes new layers available for microbial colonization. Thus, macroinvertebrates accelerate wood decay and nutrient liberation (Pereira et al. 1982; Anderson et al. 1984). The recognition, how woody debris contributes to the maintenance of biological diversity and ecosystem functions in littoral zones is crucial from the point of view of conservation. Prior to increasing human impacts, submerged wood formed an essential habitat in lakes with forested shorelines (Armitage et al. 1995), but currently woody debris is increasingly lost due to shoreline development and 
intentional removal (Francis et al. 2006; Marburg et al. 2009). In addition, according to our

407

408

409

410

411

observations, developed lakes are usually poor in more complex, decayed wood. As wood decomposition enhances microbial processes and supports secondary production of invertebrates that in turn can subsidize upper trophic levels, the loss of the woody habitats can be severe, particularly in oligotrophic and eutrophic, turbid lakes with already sparse macrophyte cover in the littoral zone.

\section{Acknowledgements}

We would like to thank the staff of the Drawieński National Park for its help with logistics and field sampling. We also thank Marta Kobyłecka for field assistance and Marek Przewoźny for the identification of Coleoptera taxa.

\section{References}

Anderson, N.H., Steedman, R.J., and Dudley, T. 1984. Patterns of exploitation by stream invertebrates of wood debris (xylophagy). Verh. Int. Ver. Theoret. Angew. Limnol. 22: 1847-1852.

Armitage, P., Cranston, P.S., and Pinder, L.C.V. 1995. The Chironomidae: the biology and ecology of non-biting midges. Chapman and Hall, London, UK.

Burlakova, L.E., Karatayev, A.Y., and Karatayev, V.A. 2012. Invasive mussels induce community changes by increasing habitat complexity. Hydrobiologia 685: 121-134. doi 10.1007/s10750-011-0791-4.

Cadotte, M.W., Carscaden, K., and Mirotchnik, N. 2011. Beyond species: functional diversity and the maintenance of ecological processes and services. J. Appl. Ecol. 48: 1079-1087

Cherugi, H., and Pattee, E. 1991. The breakdown of wood in the side arm of a large river: preliminary investigations. Verh. Internat. Verein. Limnol. 24: 1785-1788. 
Aust. J. Ecol. 18: 117-143.

Collier, K.J., and Halliday, J.N. 2000. Macroinvertebrate-wood associations during decay of plantation pine in New Zealand pumice-bed streams: stable habitat or trophic subsidy? J. N. Am. Benthol. Soc. 19: 94-111. Czarnecka, M. 2016. Coarse woody debris in temperate littoral zones: implications for biodiversity, food webs and lake management. Hydrobiologia 767 (1): 13-25. trap for benthic invertebrates exposed to fish predation? Fresh. Biol. 59: 2400-2412. indices and statistical inference. Ecology 90: 3566-3574. indicator value analyses. Methods Ecol. Evol. 3: 973-982. ecosystem processes. Trends Ecol. Evol. 16: 646-655. in aquatic habitats. Melanderia 39: 1-21. Dufrené, M., and Legendre, P. 1997. Species assemblages and indicator species: the need for a flexible asymmetrical approach. Ecol. Monogr. 67: 345-366. Limnol. Oceanogr. 52: 1239-1245. communities. Oecologia 93: 475-486. 
functional diversity and ecosystem functioning across habitats and seasons in a field experiment. J.

453

454

455

456

457

458

459

460

461

462

463

464

465

466

467

468

469

470

471

472

473

Anim. Ecol. 83: 460-469.

Francis, T., and Schindler, D.E. 2006. Degradation of littoral habitats by residential development: woody debris in lakes of the Pacific Northwest and Midwest, United States. Ambio 35: $274-280$.

Francis, T., and Schindler, D.E. 2009. Shoreline urbanization reduces terrestrial insect subsidies to fishes in North American lakes. Oikos 118: 1872-1882.

Francis, T., Schindler, D.E., Fox, J.M., and Seminet-Reneau, M. 2007. Effects of urbanization on the dynamics of organic sediments in temperate lakes. Ecosystems 10: 1057-1068.

Gabel, F., Garcia, X-F., Brauns, M., Sukhodolov, A., Leszinski, M., and Pusch, M.T. 2008. Resistance to ship-induced waves of benthic invertebrates in various littoral habitats. Fresh. Biol. 53: 1567-1578.

Golladay, S.W., and Webster, J.R. 1988. Effects of clear-cut logging on wood breakdown in Appalachian mountain streams. Am. Midl. Nat. 119: 143-155.

Guyette, R.P., Cole, W.G., Dey, D.C., and Muzika, R-M. 2002. Perspectives on the age and distribution of large wood in riparian carbon pools. Can. J. Fish. Aquat. Sci. 59: 578-585.

Harrison, S.S.C., and Hildrew, A.G. 2001. Epilithic communities and habitat heterogeneity in a lake littoral. J. Anim. Ecol. 70: 692-707.

Harmon, M.E. et al., 1986. Ecology of coarse woody debris in temperate ecosystems. Adv. Ecol. Res. 15: 133-302.

Heino, J. 2008. Patterns of functional biodiversity and function-environment relationships in lake littoral macroinvertebrates. Limnol. Oceanogr. 53: 1446-1455. 

European streams. Internat. Rev. Hydrobiol. 85: 25-48. complexity does not always decrease foraging efficiencies of piscivorous fishes. Mar. Ecol. Prog. Ser. 377: 43-49. parameters. Ecology 52: 577-586. ambush predation within a simulated seagrass habitat. J. Exp. Mar. Biol. Ecol. 176: 187-200. future directions. Hydrobiologia 685: 1-17. diversity from multiple traits. Ecology 91: 299-305. multiple traits, and other tools for functional ecology [online]. https://cran.rproject.org/web/packages/FD/FD.pdf. Sea. Mar. Biol. 13: 100-123. need? Ecol. Indic. 18: 485-492. 

Magoulick, D.D. 1998. Effect of wood hardness, condition, texture and substrate type on

497

498

499

500

501

502

503

504

505

506

507

508

509

510

511

512

513

514

515

516

517

community structure of stream invertebrates. Amer. Midl. Natur. 9: 187-200.

Marburg, A.E., Bassak, S.B., Kratz, T.K., and Turner, M.G. 2009. The demography of coarse wood in north temperate lakes. Fresh. Biol. 54: 1110-1119.

Mason, N.W.H., Mouillot, D., Lee, W.G., and Wilson, J.B. 2005. Functional richness, functional evenness and functional divergence: the primary components of functional diversity. Oikos 111: 112118.

Mathooko, J.M., and Otieno, C.O. 2002. Does surface textural complexity of woody debris in lotic ecosystems influence their colonization by aquatic invertebrates? Hydrobiologia 489: 11-20.

McKie, B.G., Woodward, G., Hladyz, S., Nistorescu, M., Presa Abos, C., and Popescu, C. et al. 2008. Ecosystem functioning in stream assemblages from different regions: contrasting responses to variation in detritivore richness, evenness and density. J. Anim. Ecol. 77: 495-504.

Moog, O. (Ed.). 1995. Fauna Aquatica Austriaca. Wasserwirtschaftkataster, Bundesministerium für Land- und Forstwirtschaft, Wien.

Murphy, L.M., and Koski, K.V. 1989. Input and depletion of woody debris in Alaska streams and implications for streamside management. North Am. J. Fish. Manage. 9: 427-436.

O'Connor, N.A. 1991. The effects of habitat complexity on the macroinvertebrates colonising wood substrates in a lowland stream. Oecologia 85: 504-512.

Pereira, C.R.D., Anderson, N.H., and Dudley, T. 1982. Gut content analysis of aquatic insects from wood substrates. Melanderia 39: 23-33.

Petchey, O.L., and Gaston, K.J. 2002. Functional diversity (FD), species richness and community composition. Ecol. Lett. 5: 402-411. 
Sabater, S., Gregory, S.V., and Sedell, J.R. 1998. Community dynamics and metabolism of

519

520

521

522

523

524

525

526

527

528

529

530

531

532

533

534

535

536

537

538

539

540

benthic algae colonizing wood and rock substrata in a forest stream. J. Phycol. 34: 561-567.

Sass, G.G., Carpenter, S.R., Gaeta, J.W., Kitchell, J.F., and Ahrenstorff, T.D. 2012. Whole-lake addition of coarse woody habitat: response of fish populations. Aquat. Sci. 74: 255-266.

Sass, G.G., Kitchell, J.F., Carpenter, S.R., Hrabik, T.R., Marburg, A.E., and Turner, M.G. 2006.

Fish community and food web responses to a whole-lake removal of coarse woody habitat. Fisheries 31: 321-330.

Schindler, D.E., Geib, S.I., and Williams, M.R. 2000. Patterns of fish growth along a residential development gradient in north temperate lakes. Ecosystems 3: 229-237.

Schindler, D.E, and Scheuerell, M.D. 2002. Habitat coupling in lake ecosystems. Oikos 98: 177-189.

Schmedtje, U., and Colling, M. 1996. Ökologische Typisierung der aquatischen Makrofauna. Informationsberichte des Bayerischen Landesamtes für Wasserwirtschaft 4/96. 543 pp.

Schmidt-Kloiber, A., and Hering, D. 2011. The taxa and autecology database for freshwater organisms [online]. URL http://www.freshwaterecology.info.

Schneck, F., and Melo, A.S. 2013. High assemblage persistence in heterogeneous habitats: an experimental test with stream benthic algae. Fresh. Biol. 58: 365-371.

Schneider, K.N., and Winemiller, K.O. 2008. Structural complexity of woody debris patches influences fish and macroinvertebrate species richness in a temperate floodplain-river system. Hydrobiologia 610: 235-244.

Smith, R.S., Johnston, E.L., and Clark, G.F. 2014. The role of habitat complexity in community development is mediated by resource availability. PLoS ONE 9: e102920. doi:10.1371/journal.pone.0102920 

periphyton and macroinvertebrates from removal of submerged wood in three Ontario lakes. Can. J. Fish. Aquat. Sci. 63: 2038-2049.

Spänhoff, B., Alecke, Ch., and Mayer, E.I. 2001. Simple method for rating the decay stages of submerged woody debris. J. N. Am. Benthol. Soc. 20: 385-394.

Stirling, G. and Wilsey, B., 2001. Empirical relationships between species richness, evenness, and proportional diversity. Amer. Natur. 158: 286-299. richness. Ecosphere 5(2): 22. doi:10.1890/ES13-00323.1. Tilman, D., Knops, J., Wedin, D., Reich, P., Ritchie, M., and Siemann, E. 1997. The influence of functional diversity and composition on ecosystem processes. Science 277: 1300-1302. indices for a multifaceted framework in functional ecology. Ecology 89: 2290-2301. deposition a main driver for the composition of benthic macroinvertebrate assemblages? Ecological Indicators 24: 589-598.

Warfe, D.M., and Barmuta, L.A. 2006. Habitat structural complexity mediates food web dynamics in a freshwater macrophyte community. Oecologia. 150: 141-154. 
565 between species richness and evenness in plant communities along a successional gradient: a study

566 from sub-alpine meadows of the Eastern Qinghai-Tibetan Plateau, China. PLoS ONE 7: e49024.

567 doi:10.1371/journal.pone.0049024.

\section{Tables}

569 Table 1. Characteristics of selected environmental variables of the study lakes.

570

\begin{tabular}{|c|c|c|c|c|c|c|c|c|}
\hline \multirow[b]{2}{*}{ Lake } & \multicolumn{2}{|c|}{ Geographical location } & \multirow[t]{2}{*}{$\begin{array}{r}\text { Area } \\
\text { (ha) }\end{array}$} & \multirow[t]{2}{*}{$\begin{array}{c}\text { Max. } \\
\text { depth }(m)\end{array}$} & \multirow[t]{2}{*}{$\begin{array}{l}\text { Mean wood surface } \\
\left(\mathrm{m}^{2} \mathrm{~m}^{-2} \text { lake bed }\right)\end{array}$} & \multicolumn{3}{|c|}{$\begin{array}{c}\text { Contribution of the wood } \\
\text { surface (\%) }\end{array}$} \\
\hline & Latitude & Longitude & & & & class 1 & class 2 & class 3 \\
\hline Sitno & $53.185327 \mathrm{~N}$ & $16.027972 \mathrm{E}$ & 61 & 7 & $0.339( \pm 0.12 \mathrm{SD})$ & 37 & 9 & 53 \\
\hline Płociczno & $53.134561 \mathrm{~N}$ & $15.997646 \mathrm{E}$ & 71 & 5 & $0.152( \pm 0.05 \mathrm{SD})$ & 48 & 19 & 33 \\
\hline Ostrowiec & $53.108776 \mathrm{~N}$ & $15.980023 \mathrm{E}$ & 120* & 7 & $0.347( \pm 0.19 \mathrm{SD})$ & 51 & 17 & 32 \\
\hline
\end{tabular}

$571 *$ approximate area of the studied riverine lake basin

572

573 Table 2. Classification of the degree of decay of FWD by external characteristics (modified from

574 Spänhoff et al. 2001).

575

\begin{tabular}{c|lll} 
Decay class & Texture & Shape & Wood colour \\
\hline 1 & intact bark, hard wood & round & original \\
2 & loose smooth bark, slight surface abrasion & round & original, darkening \\
3 & bark absent, grooves and holes in the surface & round to oval & dark
\end{tabular}

576 Table 3. Indicator species analysis of different wood decay classes. Only taxa with significance values

577 of $p \leq 0.05$ are listed.

\begin{tabular}{|c|c|c|c|c|}
\hline Wood type & Taxon & Indicator value & p-value & Frequency \\
\hline \multirow[t]{4}{*}{ class 2} & Ceratopogoninae Gen. sp. & 0.597 & 0.019 & 19 \\
\hline & Asellus aquaticus & 0.587 & 0.020 & 36 \\
\hline & Erpobdella octoculata & 0.569 & 0.013 & 36 \\
\hline & Glossiphonia palludosa & 0.566 & 0.001 & 25 \\
\hline
\end{tabular}


578

\begin{tabular}{l|llll} 
& Helobdella stagnalis & 0.532 & 0.013 & 32 \\
& Glyptotendipes pallens & 0.493 & 0.012 & 39 \\
& Gyraulus albus & 0.474 & 0.035 & 24 \\
class 3 & Platycnemis pennipes & 0.580 & 0.001 & 14 \\
& Pisidium sp. & 0.383 & 0.050 & 14
\end{tabular}

579 Table 4. Summary of one-way ANOVA results showing the effects of different wood decay classes

580 (undecayed wood, wood with loose bark, highly decayed wood) on densities of macroinvertebrate

581 functional groups. Statistically significant results are indicated by asterisks $(* \leq 0.05, * * \leq 0.01, * * *$

$582 \leq 0.001, \mathrm{~ns}=$ not significant). The functional groups are abbreviated as follows: AF - active filter

583 feeders, CG - collector-gatherers, P - predators, Sc - scrapers/grazers, Sh - shredders, Par -

584 parasites, $\mathrm{O}$ - others, NF - non feeders, Bur - burrowers, Ses - sessile/temporary sessile, Spr -

585 sprawlers/walkers, Swm - swimmers/skaters.

\begin{tabular}{l|cc} 
& & \\
Functional group & F & p-value \\
\hline AF_Bur & 5.62 & $* *$ \\
AF_Ses & 1.59 & ns \\
AF_Spr & 1.54 & ns \\
CG_Bur & 7.80 & $* *$ \\
CG_Ses & 0.54 & ns \\
CG_Spr & 4.16 & $*$ \\
CG_Swm & 9.15 & $* *$ \\
P_Bur & 1.86 & ns \\
P_Ses & 1.84 & $*$ \\
P_Spr & 1.00 & $* *$ \\
P_Swm & 4.28 & ns \\
Sc_Bur & 6.70 & ns \\
Sc_Ses & 1.20 & ns \\
Sc_Spr & 0.67 & ns \\
Sh_Ses & 0.46 & ns \\
Sh_Spr & 1.12 & $* * *$ \\
Sh_Swm & 0.77 & $* * *$ \\
Par_Spr & 1.26 & ns \\
O_Ses & 20.03 & ns \\
NF_Bur_Ses & 21.50 & ns \\
& &
\end{tabular}


588 Figure 1 A. Total abundance of macroinvertebrates (ind. $\mathrm{m}^{-2}$ ); B. Mean densities of obligate and 589 facultative xylophages (ind. $\mathrm{m}^{-2}$ ) on different wood decay classes. ' $a$ ' and 'b' indicate significant 590 differences and bars labelled with the same letters do not differ significantly from one another.

591 Figure 2. Mean values of numbers of macroinvertebrate taxa $(A)$, Shannon-Wiener index $\left(H^{\prime}\right)(B)$ and 592 evenness $\left(\mathrm{J}^{\prime}\right)(\mathrm{C})$ recorded on different wood decay classes. ' $a$ ' and 'b' indicate significant differences 593 and bars labelled with the same letters do not differ significantly from one another.

594 Figure 3. Rarefaction curves of the accumulated number of species versus accumulated number of 595 individuals (ind. $\mathrm{m}^{-2}$ ) in collected FWD samples.

596 Figure 4. nMDS plot showing the effects of various FWD decay states on macroinvertebrate 597 communities.

598 Figure 5 A. Densities (ind. $\mathrm{m}^{-2}$ ) of the three most abundant functional groups on different wood decay 599 classes. B. and C. Densities (ind. $\mathrm{m}^{-2}$ ) of other less abundant functional groups on different wood 600 decay classes. Only statistically significant results are shown. The functional groups are abbreviated 601 as follows: AF - active filter feeders, CG - collector-gatherers, P - predators, Sc - scrapers/grazers, Sh 602 - shredders, Bur - burrowers, Ses - sessile/temporary sessile, Spr - sprawlers/walkers, Swm 603 swimmers/skaters.

604 

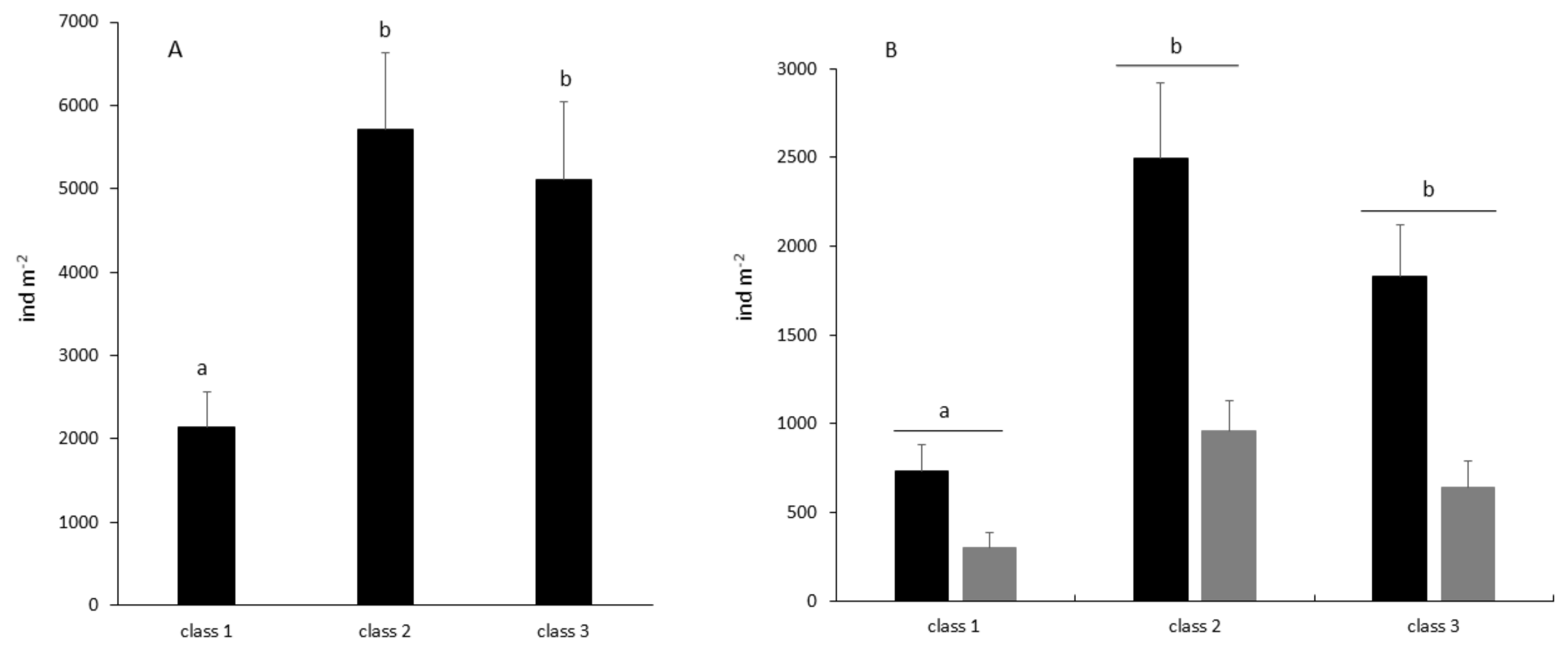

- obligate facultative 

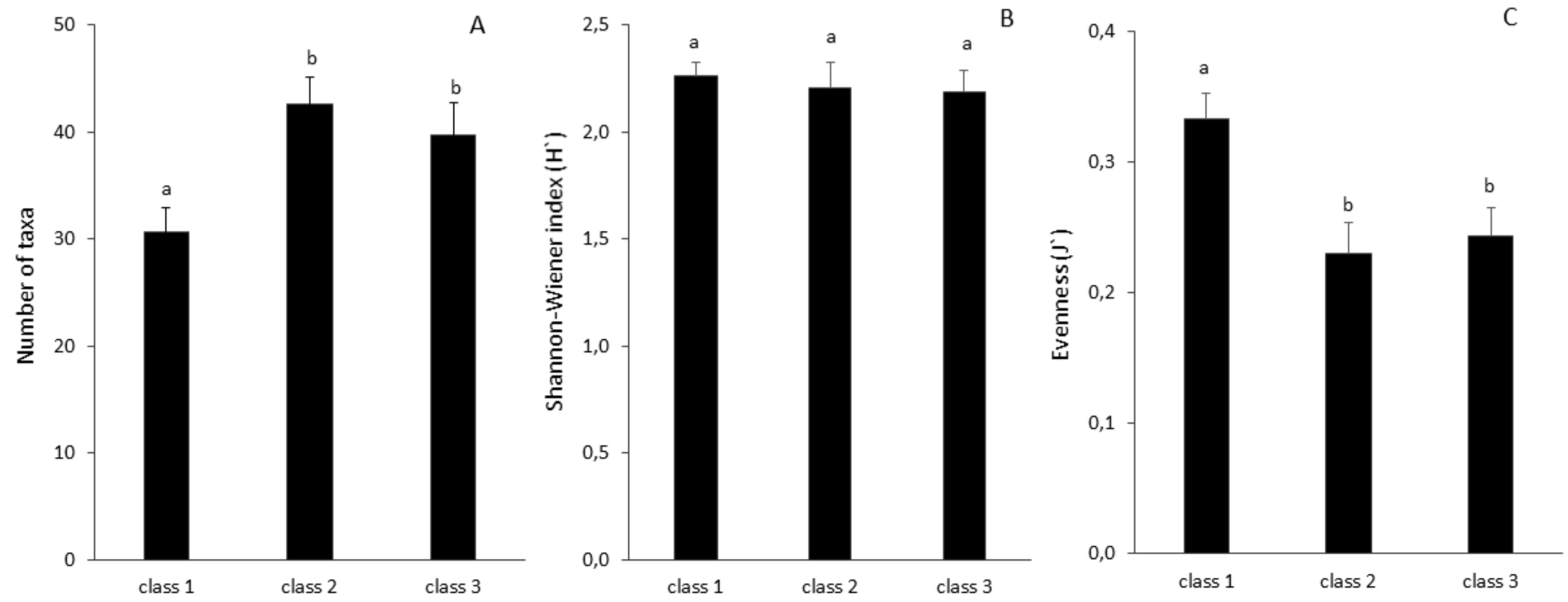


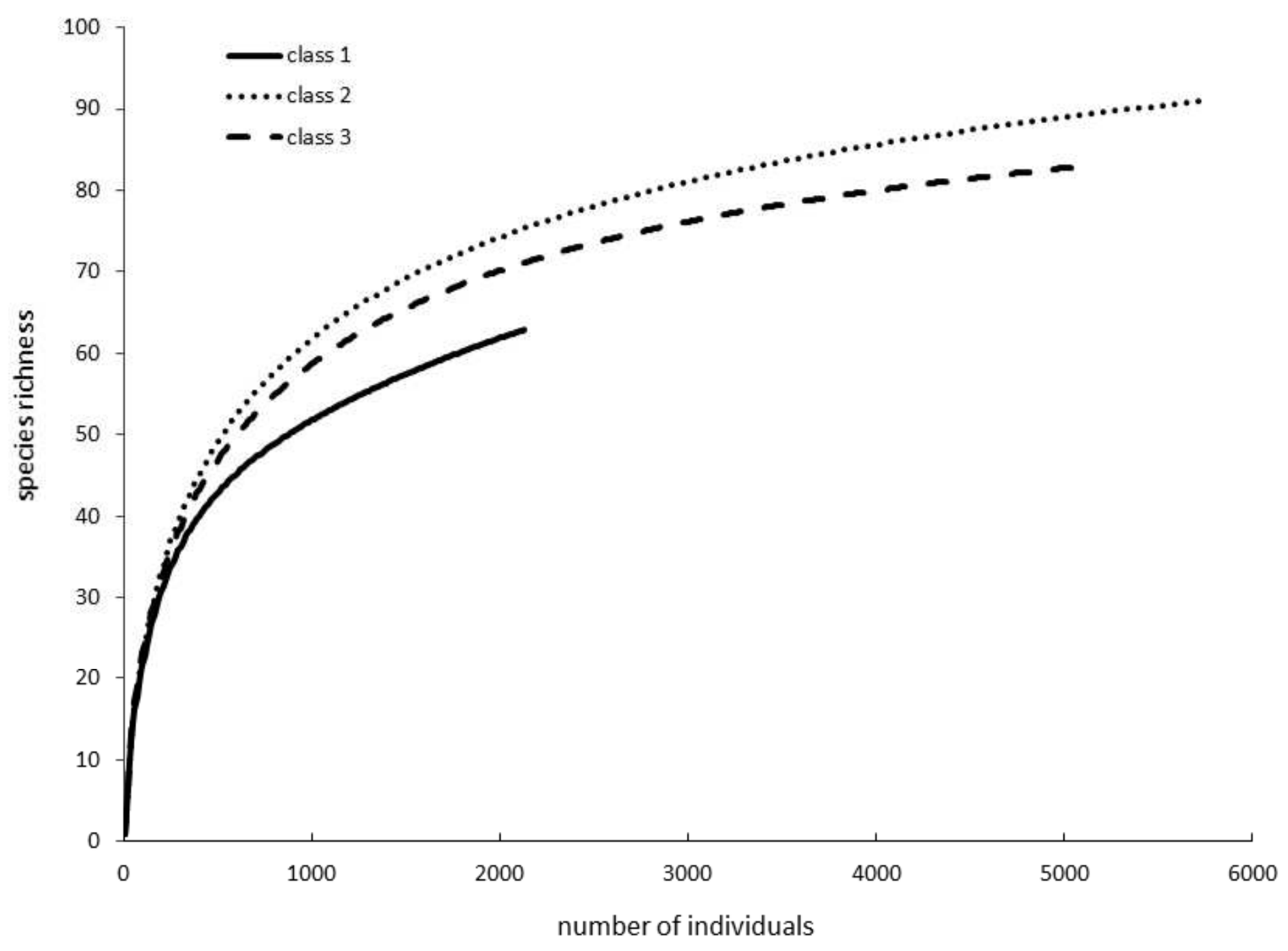




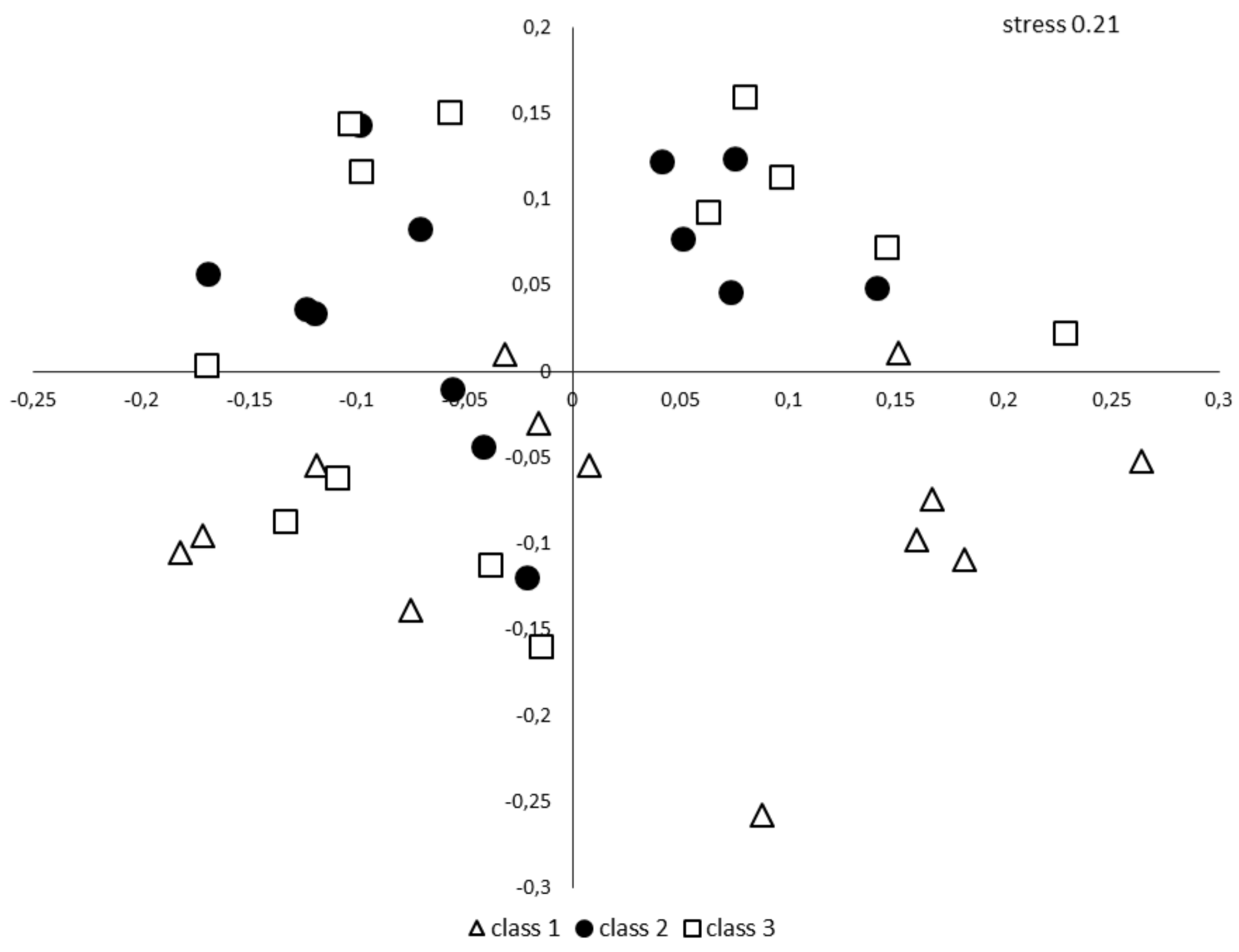



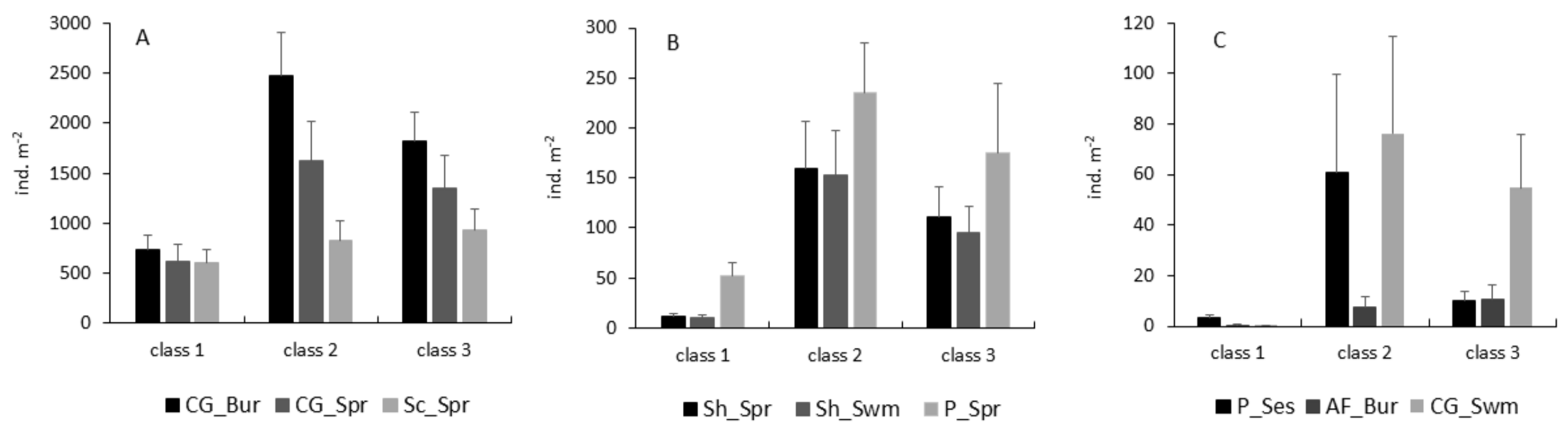


\section{Appendix A}

AQEM expert consortium. 2002. Ecological classifications by AQEM expert consortium [online]. www.aqem.de

Bauernfeind, E., Moog, O. and Weichselbaumer, P. 1995. Ephemeroptera. In: Moog, O. (ed.): Fauna Aquatica Austriaca, Lieferung 1995. Wasserwirtschaftskataster, Bundesministerium für Landund Forstwirtschaft, Wien.

Bauernfeind, E., Moog, O. and Weichselbaumer, P. 2002. Ephemeroptera. In: Moog, O. (ed.): Fauna Aquatica Austriaca, Lieferung 2002, Wasserwirtschaftskataster, Bundesministerium für Landund Forstwirtschaft, Umwelt und Wasserwirtschaft, Wien.

Buffagni, A., Armanini, D.G., Cazzola, M., Alba-Tercedor, J., López-Rodríguez, M.J., Murphy, J., Sandin, L. and Schmidt-Kloiber, A. 2016. Dataset "Ephemeroptera". www.freshwaterecology.info the taxa and autecology database for freshwater organisms, version 6.0 (accessed on 21.11.2016).

Buffagni, A., Cazzola, M., López-Rodríguez, M.J., Alba-Tercedor, J. and Armanini, D.G. 2009. Distribution and Ecological Preferences of European Freshwater Organisms. Volume 3 Ephemeroptera. Edited by Schmidt-Kloiber, A. and D. Hering. Pensoft Publishers (Sofia-Moscow). 254 pp.

Car, M., Mohrig, W., Moog, O., Oosterbroek, P., Reusch, H., Wagner, R. and Zwick, P. 1995. Diptera (except Chironomidae) (authors depending on family). In: Moog, O. (Ed.): Fauna Aquatica Austriaca, Lieferungen 1995, 2002. Wasserwirtschaftskataster, Bundesministerium für Land- und Forstwirtschaft, Umwelt und Wasserwirtschaft, Wien.

Eder, E., Hödl, W., Moog., O., Nesemann, H., Pöckl M. and Wittmann, K. 1995. Crustacea (authors depending on taxonomic group). In: Moog, O. (Ed.): Fauna Aquatica Austriaca, Lieferungen 1995, 2002. Wasserwirtschaftskataster, Bundesministerium für Land- und Forstwirtschaft, Umwelt und Wasserwirtschaft, Wien. 
Eder, E., Hödl, W., Moog., O., Nesemann, H., Pöckl M. and Wittmann, K. 1995. Crustacea (authors depending on taxonomic group). In: Moog, O. (Ed.): Fauna Aquatica Austriaca, Lieferungen 1995, 2002. Wasserwirtschaftskataster, Bundesministerium für Land- und Forstwirtschaft, Umwelt und Wasserwirtschaft, Wien.

Graf, W., Grasser, U. and Weinzierl, A. 1995. Plecoptera. In: Moog, O. (ed.): Fauna Aquatica Austriaca, Lieferung 1995. Wasserwirtschaftskataster, Bundesministerium für Land- und Forstwirtschaft, Wien.

Graf, W., Grasser, U. and Weinzierl, A. 2002. Plecoptera. In: Moog, O. (ed.): Fauna Aquatica Austriaca, Lieferung 2002. Wasserwirtschaftskataster, Bundesministerium für Land- und Forstwirtschaft, Umwelt und Wasserwirtschaft, Wien.

Graf, W., Murphy, J., Dahl, J., Zamora-Muñoz, C. and López-Rodríguez, M.J. 2008. Distribution and Ecological Preferences of European Freshwater Organisms. Volume 1 - Trichoptera. Edited by Schmidt-Kloiber, A. and D. Hering. Pensoft Publishers (Sofia-Moscow). 388 pp.

Graf, W., Murphy, J., Dahl, J., Zamora-Muñoz, C., López-Rodríguez M.J. and Schmidt-Kloiber., A. 2016. Dataset "Trichoptera". www.freshwaterecology.info - the taxa and autecology database for freshwater organisms, version 6.0 (accessed on 23.11.2016).

Hörner, K., Moog, O. and Sporka, F. 1995. Oligochaeta. In: Moog, O. (Ed.): Fauna Aquatica Austriaca, Lieferungen 1995, 2002. Wasserwirtschaftskataster, Bundesministerium für Land- und Forstwirtschaft, Umwelt und Wasserwirtschaft, Wien.

Jäch, M., Kodada, J., Moog., O., Paill, W. and Schödl., S. 1995. Coleoptera (authors depending on family). In: Moog, O. (Ed.): Fauna Aquatica Austriaca, Lieferungen 1995, 2002. Wasserwirtschaftskataster, Bundesministerium für Land- und Forstwirtschaft, Umwelt und Wasserwirtschaft, Wien. 
Janecek, B.F.U., Moog, O. and Waringer, J. 1995. Odonata. In: Moog, O. (Ed.): Fauna Aquatica Austriaca, Lieferungen 1995, 2002. Wasserwirtschaftskataster, Bundesministerium für Land- und Forstwirtschaft, Umwelt und Wasserwirtschaft, Wien.

Janecek, B.F.U., Moog, O., Moritz, C., Orendt, C. and Saxl, R. 1995. Chironomidae (authors depending on subfamily). In: Moog, O. (Ed.): Fauna Aquatica Austriaca, Lieferung 1995. Wasserwirtschaftskataster, Bundesministerium für Land- und Forstwirtschaft, Wien.

Janecek, B.F.U., Moog, O., Moritz, C., Orendt, C. and Saxl, R. 2002. Chironomidae (authors depending on subfamily). In: Moog, O. (Ed.): Fauna Aquatica Austriaca, Lieferung 2002. Wasserwirtschaftskataster, Bundesministerium für Land- und Forstwirtschaft, Umwelt und Wasserwirtschaft, Wien.

Moog, O. 1995. Functional-Feeding Guilds - Family/Genus Level. Fauna Aquatica Austriaca, Lieferungen 1995. Wasserwirtschaftskataster, Bundesministerium für Land- und Forstwirtschaft, Umwelt und Wasserwirtschaft, Wien.

Nesemann, H. and Reischütz, P.L. 1995. Bivalvia. In: Moog, O. (Ed.): Fauna Aquatica Austriaca, Lieferungen 1995, 2002. Wasserwirtschaftskataster, Bundesministerium für Land- und Forstwirtschaft, Umwelt und Wasserwirtschaft, Wien.

Schmedtje, U. and Colling, M. 1996. Ökologische Typisierung der aquatischen Makrofauna. Informationsberichte des Bayerischen Landesamtes für Wasserwirtschaft 4/96. 543 pp.

Tachet, H., Bournaud, M., Richoux, P. and Usseglio-Polatera, P. 2010. Invertébrés d'eau douce-systématique, biologie, écologie. CNRS Editions, Paris. 600 pp.

Zettel, H. 1995. Heteroptera. In: Moog, O. (Ed.): Fauna Aquatica Austriaca, Lieferungen 1995, 2002. Wasserwirtschaftskataster, Bundesministerium für Land- und Forstwirtschaft, Umwelt und Wasserwirtschaft, Wien. 
